\title{
Transition Finance and Markets
}

\author{
Deborah Cotton* \\ UTS Business School, University of Technology Sydney
}

\section{ARTICLE INFO}

\section{Article history:}

Received 17 May 2020

Revised 29 June 2020

Accepted 01 July 2020

Published 20 August 2020

\section{Keywords:}

Transition finance

Green bonds

Environmental markets

\begin{abstract}
The increased focus and agreement on the requirement for the planet to be more sustainable has led to an array of new research and financial products. The new buzz phrase is transition financing which is being seen as the path to achieving a sustainable world. The Development Assistance Committee (DAC) in the Organisation for Economic Co-operation and Development (OECD, 2019) has the main objective of transition finance is to optimise access to finance for sustainable development to avoid financing gaps or socio-economic setbacks. This chapter examines some of the products and markets in current use by financial institutions and investors. It describes their use and recent research in this area as well as some gaps in this research.
\end{abstract}

\section{Transition Finance}

\section{(i) Bonds}

The greatest level of growth and innovation in recent years is in the use of bonds as a financing instrument. Takatsuki and Foll (2019) (AXA investment managers in London) wrote guidelines for transition bonds which were published by AXA in June 2019. They suggest there hasn't been the growth in this market into what they refer to as the bulk of the real world economy i.e. heavy industry and manufacturing. It has been limited to "supranational, sovereign and agency (SSA) issuers, commercial banks and electricity utilities in Europe and North America". The DAC of the OECD investigated the support and linkages between sources of finance, both public and private. They find that domestic resources are the largest source of funding for the majority of countries studied. It was also found that they are highly dependent on public external support in the early stages of the transition.

The International Energy Agency's (IEA) Sustainable Development scenario requires demand for coal to fall by more than $50 \%$ by 2040 to achieve the $1.5^{0}$ IPPCC goal. This impacts heavily on the electricity generation sector which currently is at around $40 \%$ from fossil fuels. These bonds will focus on greenhouse gas intensive industries who do not have access to green finance but will require significant financing to make the changes required. Access to date for green bonds has been focussed on the use of the proceeds on climate and environmental activities such as wind farms and solar panels. Broadly the activities for which these transition bonds could finance include;

- Cogeneration plants

- Carbon capture storage

- Waste to energy

- Gas powered ships

- Aircraft alternative fuels

\footnotetext{
* Corresponding author. 
Increase use of recycled materials, smelting reduction and other energy reducing methods for the targeted industries

Avery (2019) suggests that while many finance organisations want to change their lending practices they are essentially caught in the clients' needs. A greater collaboration of these organisations with their clients during the structuring and deal making stages is needed. Further they suggest the green bonds are failing to change these practices or their clients' plans for investment and that sustainability linked loans are a better prospect. This issue is shown in a quote from one sustainable finance head who said "We need investors to support bonds and other financial tools that help a transition - be those called transition bonds, or dark green (or brown) bonds, rather than just looking for pure green". In fact we find that the EU is starting to move in this direction with their taxonomy including 'transition' into its lexicon when discussing green finance. Many working in this sector suggest that there is not enough involvement from the institutional investors. Avery (2019) quotes Rhian-Mari Thomas of the Green Finance Institute that "The perceived risk in emerging markets - FX risk, political risk, a lack of secondary market and liquidity - means the large amounts of capital are not getting to where they need to go. We need more investable channels and tools; possibly aggregating different projects, using warehousing techniques, for example, as well as involving concessional and philanthropic capital to credit enhance or reduce risk".

Ehlers and Packer (2017) found an increase in the financing of investments through green bonds and conclude that they should be the easiest form of finance for green projects. However, they also found that the variation in the definition of green bonds was significant. Wisniewski and Zielinski (2019) also indicated the need for clear guidelines on the definition and authorisation of green bonds and the scarcity of research in this area. So, while we find a push for a clear taxonomy and clarification there remain instruments such as unlabelled climate aligned bonds being issued. Their paper, and one by Hachenberg and Schiereck (2018), question if they are selling at a premium and are therefore not achieving are achieving an attractive risk-return relationship. There is some evidence that they trade tighter when compared to non-green bonds and government related bonds, in particular for A rated bonds. They suggest the higher price of the green bonds may be due in part to the additional certification and verification required. Zerbib (2019) found an average two basis point yield for green bonds lower than conventional bonds however demand remained strong for these environmental bonds in their study of European and US bond markets.

Sartzetakis (2019) looks specifically at green bonds as the preferred instrument to use for financing the transition to a low carbon economy. However, there are a few quite specific and interesting issues which are discussed. One of these is the question of intergenerational equity where he asks whether the current generation should bear all the costs of climate change mitigation. While this appears a more of a philosophical question, he addresses it by suggesting debt is an ideal tool for spreading the cost across generations. Specifically, a combination of taxes and debt was recommended. This appears a good method but does this address the social optimum and the aging population including the many issues around this such as the changes that will occur due to climate change? Here we might consider the significant changes to the types of work, where and how we work as well as the health aspects that will be affected. Are financial instruments used going to have an impact on any, or all, of these issues plus the many more that could be suggested? Beyond this Sartzetakis (2019) looks at the amounts of funding that are going to be required to renew and change the infrastructure to meet the new energy source needs for the low carbon economy. A real issue that is already evident in the green bond market is the concern around greenwashing and transparency.

The Green Bonds State of the Market 2018 (Climate Bonds Initiative, 2019) report provided the following information on the green bond market in 2018 in US Dollars:

Table 1. Top 3 Countries and their Top Financiers of Green Bonds in 2018

\begin{tabular}{llll}
\hline Country & \$USD & Issuer & \$USD \\
\hline USA & $34.2 \mathrm{bn}$ & Fannie Mae & $20.1 \mathrm{bn}$ \\
China & $31 \mathrm{bn}$ & Industrial Bank & $9.6 \mathrm{bn}$ \\
France & $14,2 \mathrm{bn}$ & Republic of France & $6 \mathrm{bn}$ \\
\hline
\end{tabular}

Source: Green Bonds State of the Market 2018

We see the dominance of sovereign funds and large financial organisations. Importantly though the development banks which were early adopters of this type of investment. Geographically the largest proportion is in the US, closely 
followed by other developed economies such as Canada and Germany. Interestingly there was significant growth in China but this level of growth had all but disappeared by 2017.

The growth has been strong in recent years and appears to be stabilising. While the majority of the funding is still into renewable energy there has been an increase into low carbon buildings and energy efficiency. Other areas of growth include transport while waste, land use and adaptation remain small.

A better understanding of the market is needed by investors for this market to grow for it to have the desired effects. This would include information of each project and its' progress including financial returns and environmental benefits.

It is only through clarity of these that the green bond market will be a useful instrument that is confidently invested in by the large fund managers. This concept, and the greenwashing mentioned earlier, engenders an interest in understanding more around the taxonomy and the different metrics used. For example, we can consider the UN's Sustainable Development Goals (SDGs), of which there are 17, or the EU taxonomy for sustainable activities, which is applied to screening criteria for 67 activities, or the Task Force on Climate-related Financial Disclosures (TCFDs) which focusses on climate issues more specifically than the other two.

\section{Future research topics:}

- Easy research includes the need for some updating from previous work due to the relative newness of, and growth in, green bonds in recent years - such as who are the investors, is public support still required, what is the growth and in what types of investments e.g. wind farms or waste?

- What would/could transition bonds look like? If investing in e.g. waste to energy or smelting reduction technologies would these instruments be positioned differently or structured differently? Is there a market for these if institutional investors are still reticent about the more familiar green energy bonds?

- Some recent research suggests that green bonds are expensive compared to their non-green bond counterparts but it is not clear why? Is it really the case or are the risks not being properly accounted for? Does the uncertainty of what green bonds really are add to these issues?

- It has been suggested that bonds are the best way to spread the cost of climate change mitigation across generations - is this the case? Should it be spread in the first place and why?

- Green bond growth in China was strong but this growth has slowed. Why is this the case or in fact is it correct? This would need to be verified using up to date data and this may provide an understanding of why have they moved their focus away from these investments.

\section{(ii) Low-carbon transition}

Transition pathways include a broad range of risks and uncertainties, these are addressed in Narratives of Low-Carbon Transitions - Understanding Risks and Uncertainties. While these are assessing the risks in particular for the lowcarbon pathways for the energy sector transition it allows some understanding of what is required for risk assessment when using the types of transition financing being discussed in chapter 9 (van Vliet, O, 2019). Displayed below as an example is Table 2 using data from the book which looks at the different types of risk in Switzerland:

Table 2: Risks to successful expansion of renewable sources of electricity in Switzerland $(\mathrm{CH})$

\begin{tabular}{llllll}
\hline Barriers & Hydropower & Rooftop PV & Utility scale & Offshore wind & Mediterranean CSP \\
& & & wind/PV & & \\
\hline High Investment & Compounded by low & Ameliorated by & Compounded by low & Compounded by & Compounded by low \\
costs & prices & FIT and fees & prices & low prices & prices \\
Landscape/ & Only for large hydro & Minor & Unwanted & Low population if & Low population in \\
Visual impact & & & & far offshore & desert \\
Permitting & Nature compensation & Building owner's & Challenges expected & Transmission line & Transmission line \\
& done & permission needed & & may be challenged & may be challenged
\end{tabular}




\begin{tabular}{llllll}
\hline Barriers & Hydropower & Rooftop PV & Utility scale & Offshore wind & Mediterranean CSP \\
& & & wind/PV & \\
\hline Intermittency & Base load and & Diurnal, weather & Diurnal, weather and & Relatively stable, & Thermal storage \\
& dispatchable & and seasonal & seasonal & better in winter & reduces \\
Energy & Swiss source & Swiss source, need & Swiss source, need & Contributes to & Contributes to \\
independence & & balancing & balancing & diversification & diversification \\
\hline
\end{tabular}

Source: Narratives of Low-Carbon Transitions

Other risks associated with transition finance to a low-carbon economy may be to the economy more broadly, in particular to carbon-intensive industries. These industries may find their asset values to be adversely affected in particular with any abrupt changes to their energy sources or allowed emission outputs. As noted by Semieniuk et. al. (2019) much climate policy requires rapid support for low carbon technologies via the transition finance which may leave the carbon intensive firms with stranded assets and an inability to change fast enough. These impacts will not be isolated to a few companies but rather have a broader impact on the economy.

An investigation by Owen et. al. (2018) found the need for a 'finance ecosystem' approach to ensure a range of forms of finance for low carbon investment that would support the sector. This ecosystem would include both private and public sector funding. The finance gap, or lack of funding into this market, would be a significant constraint for businesses trying to work in this low carbon sector and is most commonly found in low income countries and for longer term investment requirements. This paper also discusses the need for scaling up this funding which is currently focussed often on pilot projects - of interest for future research might be where is this funding come from? What does it look like? Is this need similar to any previous financing needs such as information technology? They also note "a lack of evaluations looking at additionality and the demonstrator effect, in order to effectively assess whether public sector support is crowding out or crowding in investment. This requires the development of assessment methodologies that address displacement of private investment and the counterfactual questions such as: how much co-financing from the private sector would have occurred without public sector support. This evidence of the impact of public sector funded interventions is needed - alongside a greater focus evaluating the green innovation impact on the wider economy - to identify where public funding can have the biggest impact on the transition to a low carbon economy."

\section{Future Research Topics:}

- Barriers to entry and risks associated with this kind of investing is highlighted in the Swiss report e.g. the intermittent supply and costs of storage or impact on landscape. Some studies in different contexts have used logit analysis to determine willingness to pay to keep wind farms etc. out of particularly beautiful areas. This would be an interesting place to do this kind of analysis in particular if it could include the other costs of implementing these types of renewable energy supplies.

- While there has been some research on stranded assets there remains a lack of clear understanding on how these impact not just on the companies who have them but also the broader community. Are the costs and risks of stranded assets being included in transition investing and if so how and to what extent?

\section{Systems and Policies and the New Green Deal}

Discussion around what kind of policy is required to achieve the emission targets set in Paris in 2016 has occurred since then. The difference in the most recent discussions is less about who needs to agree and to what levels and more about what needs to happen in the finance sector to facilitate the changes required. There has been a certain amount of agreement that a policy mix is required which would include the use of "fiscal instruments, targets and standards; public private co-funding schemes; financial regulation; and disclosure practices." (Lamperti et. al., 2019, p1.) The focus in their paper is not on simply scaling up the existing financial sources but more on the quality and de-risking these investments. They found a significant difference in what types of research and development was being funded by public and private i.e. public funding focussed on less commercial ventures such as tidal and wave energy while private funding was predominantly in the established technologies such as wind. Further the private funds only 
entered the higher risk areas once there was existing public funds invested via subordinated debt. In their final policy insights they state that "Institutional investment may not be enough to vastly increase renewable energy investments to a scale consistent with mitigation scenarios." (Lamperti et. al., 2019, p. 11). Additionally, they call for investors to be patient, not overly risk averse and be prepared to take on projects that will not provide strong returns.

As discussed earlier the SDG's are taking their place in identifying the areas of interest or application of investments. There has been some research to date on the SDG's with a few explaining what they do and their role in the growth of sustainable development (Wood et. al. (2018), Leal Filho et. al. (2018), Schmidt-Traub et. al. (2017)). The need for these to be given a greater level of priority in research for interdisciplinary research, the development of local level research and to highlight the scientific results to a greater range of stakeholders were considered an important use of these goals. Environmental goals were considered to have a large focus among the SDGs and that the interaction among these had significant benefits as seen in Wood et. al. (2018).

The EU Taxonomy is the most recent of the metrics and works alongside the SDGs, it was devised by the European Commission to inform its work on the action plan for financing sustainable growth which was established in 2018. It sets out criteria for 67 activities that are making a contribution to climate change mitigation and works with the mandate of the technical expert group on sustainable finance. In brief the report states that "The EU Taxonomy is a tool to help investors, companies, issuers and project promoters navigate the transition to a low-carbon, resilient and resource-efficient economy." (EU Technical Expert Group on Sustainable Finance, p. 2). Not surprisingly there has as yet been little research on this taxonomy however we do find a short comment by Lai (2019) where he states that Japanese asset managers are sceptical of the rule based taxonomy and their preference is for a more market led approach.

Schmidt-Traub et. al. (2017) investigated the gaps in scope and coverage of the various indexes and dashboards which is of interest to future researchers in evaluating the various metrics that are currently in use. Other papers explore more specific applications including in nursing, victims of unsustainability and wicked problems such as the challenge of food safety versus food security. There are many more specific areas to look at which could be better understood by reading some of the existing work by authors such as Rush (2019), Benton and Shaffer (2016) and Kopnina (2015).

The TCFDs were recommended in 2017 and are strictly focused on climate related issues and are more similar to the EU Taxonomy than the broader SDGs. They provide recommendations on how to disclose any climate related financial risks as well as opportunities. It provides recommendations around governance issues such as board oversight of these issues as well as management's role in assessing and managing these risks and opportunities. Strategy and risk management practices are recommended as well as guidance around metrics disclosure, scopes (1, 2 and 3) as well as targets used to manage the risks. To date much of the research around TCFD's has been predominantly in the form of commentaries such as Tyagi (2018) who stated that the oil and gas industry are possibly the only sector with the necessary expertise and position to adapt and strengthen the risks and opportunities the TCFDs are designed to identify. In a similar vein Eccles and Krzus (2019) conducted a field experiment prior to the publication of the TCFDs on fifteen of the largest oil and gas companies by market capitalisation to determine how easily they could be implemented. They found that a number of the required disclosures were already in existence as voluntary and recommended further studies be conducted to see how these have been implemented since the publication.

The Green New Deal is not a new idea as such having been first termed by Thomas Friedman in 2007 to raise the idea of a transition away from fossil fuels. It appeared to be gaining new ground in recent years with a resolution going to US Congress in 2019 however it was voted down in the Senate by 57 to 0 . So while it is not looking likely in the current political environment in the US it appears to have greater resonance in the banking and investment community who are looking more into sustainable products for the long term. The goals of this Green New Deal included job creation in the transition in areas such as sustainable agriculture, conservation and infrastructure; workers displaced from their current jobs to receive income and benefits as they transition to alternative work; public, community and worker ownership of the energy system; and end all subsidies for fossil fuels and impose a greenhouse gas fee or tax.

The previous version of this green new deal had a large amount of academic research undertaken looking at it from a variety of perspectives. An opinion piece in Nature by Barbier (2010) gave two key reasons for countries to get behind this new transition; "First, international competitiveness: those countries that have spent large amounts on green projects are now better placed in the race for technological superiority. Second, deficit reduction: reducing dependency on foreign oil and raising cash through carbon taxes or auctioned permits will ease national debts." He discusses leaders and laggards and cites worsening effects of climate change including energy insecurity, environmental degradation and global poverty as some of the results on inaction. Table 3 below shows data from 
2009 as described by Barbier (2010) showing the percentage of GDP in green investments by country compared to the $1 \%$ target of the deal.

Table 3: \% of GDP in Green Investment by Country

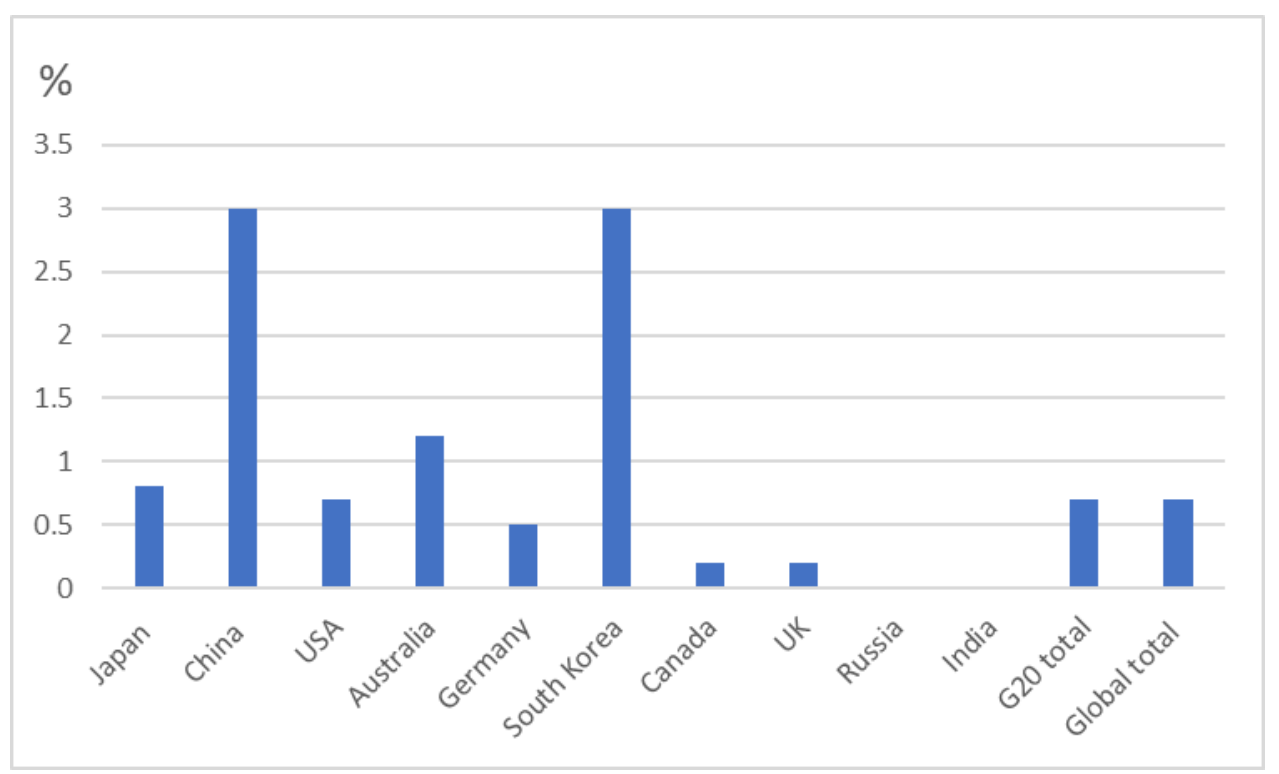

Source: Barbier (2010)

A little later Schwartzman (2011) looked at the deal from the perspective of the success of the New Deal enacted during the Great Depression in the 1930's. He argues that the aim of that deal was to save capitalism and that the class struggle that ensued was what resulted in the formation of the industrial unions in 1936. He goes on to suggest that this New Green Deal could provide an opportunity for another such research stating one of the goals i.e. the creation of worker owned factories to be a possible catalyst. While this angle of the research is a little different from the expected it is often these completely new ways of analysing an issue that are the most interesting and innovative/productive. Herman (2105) continued this discussion into the impact on equality finding the concepts of this earlier version to in fact have a furthering of the unequal distribution on environmental and economic assets. Four years later White (2019) offered some notes on how some of the disengagement shown in the vote in the US Congress in 2019 could be ameliorated. He states that "This paper is written from the sense that it may well be more productive now to acknowledge that all conceivable programs for just transition are going to be socio-technical in nature, multi-scalar and, by definition, concerned with designing low-carbon futures." (p. 1).

The discussion of the progress requires a look at transition finance on a smaller scale - what are the banks doing with personal lending and small business loans? This is the less 'sexy' side of transitioning finance but may be interesting to better understand and may provide some interesting research opportunities. We know that many of the large financial institutions are offering cheaper loans if you are putting solar panels on your home or installing a water tank. Similarly small businesses have similar 'energy saving' savings on loans available as well as the more direct interest rate reductions if they are in the business of green technologies. In Australia a comparison website (Finder, 2019) state "A green personal loan is a personal loan specifically designed to fund the purchase of specific energyefficient products, such as electric or hybrid cars, energy-efficient air conditioning or solar panels. These loans can be secured or unsecured and have terms ranging from six months up to seven years. They also tend to feature flexible borrowing limits based on the items you want to purchase, and many lenders allow you to make early repayments without penalty. Green personal loans are a good choice for most borrowers who have a good credit score." So while not exactly indicating much of a discount we find globally this is more clear. The Canadian bank RBC offer a $1 \%$ discount on their interest rates for loans over \$5,000 when purchasing certain energy saving products. The World GBC Europe Regional Networks (2018) wrote the report 'Creating an Energy Efficient Mortgage for Europe: Towards a New Market Standard' which sets out a plan for how mortgage lenders and borrowers can help tackle climate change by improving millions of properties across Europe. It proposes energy efficiency mortgages to be made available across Europe and calls on lenders, industry and government to work together to achieve these goals. There appears to be a growth area for transition finance in the banking sector but little to no growth in the research covering this new and interesting part of the 'road to a sustainable planet'. 
Future Research Topics:

- The need for investors to be patient and willing to accept a lower return is the opposite to what is mostly in place in fund management and appears contradictory. So what does this mean these investments look like? Are they a mere addition to existing financial instruments or is something completely new required?

- While the SDG's are still very new there is an array of research opportunities including how or if they can be applied globally or would they have to be managed to fit within other economies?

- Does the new taxonomy emerging help investors to better understand the green bonds and other transition finance and their investment prospects?

- The work done by Eccles and Krzus (2019) prior to the publication of the TCFDs would be interesting to follow up and determine exactly how well they are managing post publication.

- What changes have or are likely to occur under the Green New deal and how likely is the creation of worker owned factories being created?

- There is a great deal to explore in how or if the Green New Deal is implemented and a vast array of consequences under any guise - all of which encourage interesting research exploration e.g. who are the leaders and the laggards and why?

- A little researched area of finance in general are the lending practices of the large financial institutions around the world which would be greatly enhanced with an investigation of the lending practices associated with the view to essentially green lending on a small and medium scale. Simpson et. al. (2016) looked at the GFC as a driver for more responsible mortgage lending and may provide a sound way to undertake this kind of analysis.

\section{Markets as transition instruments}

Globally there are a vast array of environmental markets. The major markets we think of are those related to climate change/energy/carbon such as the European Emissions Trading Scheme and the California Emissions Trading Scheme. We will commence by reviewing these markets and then proceed to investigate the other less researched markets. The most recent report by the International Carbon Action Partnership (ICAP) provides information on these markets including how they are traded, sectoral coverage and allowance prices. It suggests that almost 1 in 6 of the global population lives in a country/region or city in which an ETS is in force. Currently the operating ETS are set up in Table 4 below in order of levels of coverage of a scheme:

Table 4: Emissions Trading Schemes

\begin{tabular}{|c|c|c|c|}
\hline Supranational & Countries & Provinces and States & Cities \\
\hline \multirow{10}{*}{$\begin{array}{l}\text { EU member states }+ \\
\text { Iceland, Lichtenstein and } \\
\text { Norway }\end{array}$} & Kazakhstan & California & Beijing \\
\hline & Mexico & Connecticut & Chongqing \\
\hline & New Zealand & Delaware & Saitama \\
\hline & Republic of Korea & Fujian & Shanghai \\
\hline & Switzerland & Guangdong & Shenzhen \\
\hline & & Hubei & Tianjin \\
\hline & & Maine & Tokyo \\
\hline & & Maryland & \\
\hline & & Massachusetts & \\
\hline & & New Hampshire & \\
\hline
\end{tabular}




\begin{tabular}{lll}
\hline Supranational & Pountries & Cities \\
\hline & New Jersey & New York \\
Nova Scotia & Québec \\
Rhode Island & Vermont \\
\hline
\end{tabular}

Source: ICAP, Status Report 2020

The best known and most widely traded is the EU ETS and has had the most research already undertaken on it. Other schemes and research undertaken have come and gone including the Australian Emissions Trading Scheme where Australia was an early adopter however the political environment caused its demise. Interestingly this political effect has been investigated recently in Britain, Germany, Australia and New Zealand with a greater level of investigation required to be able to form a comprehensive view of the impact. A few reviews have been undertaken of emissions trading (Ranson et. al. (2016), Ellerman et. al. (2015), Jotzo et.al (2018)) which provide some interesting issues which may provide further investigation. The importance of linkages between schemes and across jurisdictions which may provide a better global coverage and accountability is discussed both explicitly in some of these and other papers. As noted in Table 4 above, the city-based approach in China has dominated but as Jotzo et.al. (2018) show there is a broader approach being applied, in this growing part of the global economy a better understanding of what is taking place there would benefit greatly the growth in knowledge of global emissions management. Other research has investigated the carbon emissions schemes and corporate responsibility (Kolk and Pinkse, 2017).

The lesser known markets include water quality (and quantity) markets, habitat and biodiversity markets and wetland markets in the US. Below is a summary of these markets:

Table 5: U.S. Environmental Markets

\begin{tabular}{|c|c|}
\hline Market & Summary \\
\hline Water Quality & $\begin{array}{l}\text { Goal to reduce pollution of waterway by land managers to meet the Clean Water Act requirements. To date it } \\
\text { has not been widely adopted. At trading's core, a buyer (e.g. a pollution source such as a municipal wastewater } \\
\text { facility) purchases water quality improvements, or credits, from a seller (e.g. a farmer installing a buffer along a } \\
\text { stream to capture sediment runoff) that reduces its pollutants beyond what it is required to do. In order for trades } \\
\text { to occur, the seller needs to reduce pollution more cost effectively than the buyer. Both buyers and sellers will } \\
\text { need to control their own pollution to some minimum level, or baseline, before generating credits (U.S.EPA, } \\
2007, \text { p29). }\end{array}$ \\
\hline Water Quantity & $\begin{array}{l}\text { Water quantity markets, including groundwater offsets and in-stream buybacks, operate when water rights are } \\
\text { appropriated for non-consumptive use, or when water rights are shifted between users to reallocate resources } \\
\text { within a watershed. }\end{array}$ \\
\hline Wetland & $\begin{array}{l}\text { Markets for wetlands are used to create incentives for landowners to improve the ecosystem of their land and } \\
\text { form part of the Clean Water Act Section } 404 \text {. }\end{array}$ \\
\hline $\begin{array}{l}\text { Biodiversity and } \\
\text { Habitat Markets }\end{array}$ & $\begin{array}{l}\text { Environmental markets for habitats create incentives for landowners to improve ecosystem services on their } \\
\text { lands. These markets are often incentivized by regulatory programs such as the Endangered Species Act, though } \\
\text { they may also be voluntary. }\end{array}$ \\
\hline Carbon Markets & $\begin{array}{l}\text { Increasing atmospheric concentrations of greenhouse gases (GHGs) such as carbon dioxide, methane, and } \\
\text { nitrous oxide cause changes in temperature and climate. Environmental markets for carbon and GHG can } \\
\text { provide funding for conservation practices that decrease carbon dioxide or other GHG emissions. }\end{array}$ \\
\hline
\end{tabular}

Source: United States Department of Agriculture 
When looking at social markets we don't find the level of depth as for these more widely recognised environmental markets. However, it is clearly understood that a sustainable world includes social elements. Eizenberg and Jaboreen (2017) state that efforts toward a sustainable planet will be undermined without socially oriented practices. They suggest it requires recognition that vulnerable groups will bear a large amount of the burden of climate change for example and this is exacerbated by their lack of a voice. Their proposition is that participation by all groups of society will increase the efficacy of any strategies towards sustainability. An important financial instrument used in this area are the social impact bonds (SIBs) and these have been widely used, and for the most part successful, in achieving their goals whether they are reducing recidivism, keeping children with their families or building affordable housing. What they are missing is a market in which they can be traded leaving them a difficult investment proposition for fund managers needing liquidity. The London Stock Exchange has listings for Charity Bonds which provides an idea of how SIBs may have an avenue for trading.

\section{Future Research Topics}

- Of interest to researchers looking at the broad range of environmental markets in the US would include their success rate in improving their targeted issues, the take up of these instruments and who is benefiting. We assume that the major benefactor is the environment however for these markets to be viable they require an ability to trade and financial benefits (or at least not losses) for those buying and selling in them.

- There is little to no research looking at making SIBs a liquid security and if they are to achieve a greater level of importance in the implementation of social benefits as benefits to sustainability this may be a good place to start.

\section{Conclusion}

These financial and sustainability related instruments and markets are significantly under researched using scientific and independent methodologies. There has been significant growth in these areas in recent years and therefore they have increased without much clear understanding of their impacts. We see that transition finance includes green bonds whose growth has been exponential globally however we are as yet uncertain if they are working, are they targeted properly or if they correctly priced given their risk and return. Not included in the suggestions by area we see that political agendas play a significant role in the markets and instruments discussed. The financial markets have also been reliant of political will which vacillates over time as can be seen currently and would be interesting to investigate. The role of research to provide facts to the conversation can only be a benefit to a sustainable future.

\section{References}

Avery, H. (2019, December 3) Six ways to fix sustainable finance - 4: Develop transition finance. Retrieved from https://www.euromoney.com/article/b1j97tzw2n0zhq/six-ways-to-fix-sustainable-finance-4-develop-transitionfinance

Barbier, E. (2010) How is the Global Green New Deal going? Nature. Vol. 464, pp. 832-833.

Benton, D. and Shaffer, F. (2016) How the nursing profession can contribute to sustainable development goals. Nursing Management. Vol. 23 (7), pp. $29-34$

Climate Bonds Initiative (2019, March 6) Green Bonds the State of the Market 2018. Retrieved from https://www.climatebonds.net/resources/reports/green-bonds-state-market-2018

Eccles, R.G. and Krzus, M.P. (2019) Implementing the Task Force on Climate-related Financial Disclosures Recommendations: An Assessment of Corporate Readiness. Schmalenbach Business Review. Vol. 71, pp. 287-293

Ehlers, T. and Packer, F. (2017, September 17)) Green Bond Finance and Certification. BIS Quarterly Review September 2017. Available at SSRN: https://ssrn.com/abstract=3042378

Ellerman, A.D., Marcantonini, C. and Zaklon, A. (2015) The European Union Emissions Trading System: Ten Years and Counting. Review of Environmental Economics and Policy. Vol. 10 (1) pp. 89-107

Eizenberg, E. and Jaboreen, Y. (2017) Social Sustainability: The New Conceptual Framework. Sustainability 2017, 9(1), 68; https://doi.org/10.3390/su9010068

EU Technical Expert Group on Sustainable Finance, Taxonomy Technical Report (2019) Retrieved from https:/ec.europa.eu/info/sites/info/files/business_economy_euro/banking_and finance/documents/200309sustainable-finance-teg-final-report-taxonomy en.pdf

Finder (2020), Retrieved from https://www.finder.com.au/solar-panel-finance 
Hachenberg, B. and Schiereck, D. (2018). Are green bonds priced differently from conventional bonds? Journal of Asset Management. Vol. 19(6), pp. 371-383

Herman, C. (2015) Green new deal and the question of environmental and social justice. Global Labour University Working Paper, No. 31, International Labour Organization, Geneva.

International Carbon Action Partnership (2020) Emissions Trading Worldwide, Status Report $2020 . \quad$ Retrieved from https://icapcarbonaction.com/en/icap-status-report-2020

Jotzo, F., Karplus, V., Grubb, M., Loschel, A., Newhoff, K,. Wu, L. et. al. (2018) China's emissions trading takes steps towards big ambitions. Nature Climate Change. Vol. 8, pp. $265-267$

Kolk, A. and Pinkse, J. (2017) The Influence of climate change regulation on corporate response: the case of emissions trading. Chapter 4 in Corporate Responses to Climate Change, Edited by R. O'Sullivan, Published by Taylor and Francis Group.

Kopnina, H. (2015) The victims of unsustainability: a challenge to sustainable development goals. International Journal of Sustainable Development and World Energy. Vol. 23 (2), pp. 113 - 121

Lai, K. (2019) High hopes for EU sustainable finance taxonomy. International Financial Law Review. Publication date October 10, 2019. $\quad$ http://ezproxy.lib.uts.edu.au/login?url=https://search-proquestcom.ezproxy.lib.uts.edu.au/docview/2313234428?accountid=17095

Lamperti, F., Mazzucato, M., Roventini, A. and Semieniuk, G. (2019) The Green Transition: Public Policy, Finance and the Role of the State. Quarterly Journal of Economic Research. Vol. 88(2), pp. 73-88.

Leal Filho, W., Azeiteiro, U., Alves, F., Pace, P., Mifsud, M., Brandli, et. al. (2017) Reinvigorating the sustainable development research agenda: the role of the sustainable development goals (SDG). International Journal of Sustainable Development and World Ecology. Vol. 25 (2), pp. 131-142

OECD (2019) Transition Finance 2019, Retrieved from https://www.oecd.org/dac/financing-sustainabledevelopment/development-finance-topics/Transition-Finance-Main-Findings-2019.pdf

Owen, R., Brennan, G. and Lyon, F. (2018) Enabling investment for the transition to a low carbon economy: government policy to finance early stage green innovation. Current Opinion in Environmental Sustainability. Vol. 31, pp. 137-145

Ranson, M. and Stavins, R.N. (2016) Linkage of greenhouse gas emissions trading system: learning from experience. Climate Policy. Vol. 16(3), pp. $284-300$

Rush, E. (2019) Wicked problems: the challenge of food safety versus food security - working towards the SDG goals? European Journal of Clinical Nutrition. Vol. 73, pp. 1091 - 1094

Sartzetakis, E.S. (2019) Green Bonds as an instrument to finance low carbon transition. Working Paper, Bank of Greece, Eurosystem

Schmidt-Traub, G., Kroll, C., Teksoz, K., Durand-Delacre, D. and Sachs, J.D. (2017) National baselines for the Sustainable Development Goals assessed in the SDG Index and Dashboards. Nature Geoscience. Vol. 10, pp. 547 - 555

Schwartzman, D. (2011) Green New Deal: An Ecosocialist Perspective. Capitalism Nature Socialism. Vol. 22(3), pp. 49 - 56

Semieniuk, G., Campiglio, E., Mercure, J., Volz, U. and Edwards, N.R. (2019) Low-carbon transition risks for finance. Interdisciplinary Reviews: Climate Change (In Review).

Simpson, G., Kern, T. and McGuiggan, N. (2016) The global financial crisis: A driver for more responsible mortgage lending in New Zealand. International Journal of Interdisciplinary Studies. Vol. 11(2), pp. 1 - 17

Task Force on Climate-related Financial Disclosures, https://www.fsb-tcfd.org/

Takatsuki, Y. \& Foll, J. (2019, June 10) Financing brown to green: Guidelines for Transition Bonds. Retrieved from https://realassets.axa-im.com/content/-/asset_publisher/x7LvZDsY05WX/content/financing-brown-to-greenguidelines-for-transition-bonds/23818

Tyagi, S. (2018) What comes next: responding to recommendations from the task force on climate-related financial disclosures (TCFD). The APPEA Journal. Vol. 58(2), pp. 633-636

UBS Editorial Team, (2019, February 12) The Green New Deal - paper produced for marketing purposes. Retrieved from https://www.ubs.com/global/en/wealthmanagement/marketnews/home/article/ jer_content.1002317683.file/PS9jb250ZW50L2RhbS9pbXBvenR1ZC9jaW9y ZXN1YXJjaC9wZGYvMTQvMTIvNzIvNS8xNDEyNzI1L2VuL3VzLzE0MTI3MjUucGRm/1412725.pdf

United States Department of Agriculture, Environmental Markets. Retrieved from https://www.oem.usda.gov/

Van Vliet, O. (2019) Switzerland: risks associated with implementing a national energy strategy. In Kopp, S., Lieu, J. and Nikas, A. Eds. Narratives of Low-Carbon Transitions Understanding Risks and Uncertainties, Routledge Studies in Energy Transitions.

White, D. (2019) Just Transitions/Design for Transitions: Preliminary Notes on a Design Politics for a Green New Deal. Capitalism Nature Socialism. DOI: 10.1080/10455752.2019.1583762

Wisniewski, M. and Zielinski, J. (2019) Green bonds as an innovative sovereign instrument. Ekonomia i Prawo. Vol. 18(1), pp. $83-96$

Wood, S.L.R., Jones, S.K., Johnson, J.A., Brauman, K. A., Chaplin-Kramer, R., Fremier, A., et al. (2018) Distilling the role of ecosystem services in Sustainable Development Goals. Ecosystem Services. Vol. 29 (A), pp. $70-82$

World GBC Europe Regional Networks (2018, September 24) Creating an Energy Efficient Mortgage for Europe: Towards a New Market Standard. Retrieved from https://www.worldgbc.org/news-media/creating-energy-efficient-mortgageeurope-towards-new-market-standard-0 
Zerbib, O.B. (2019) The effect of pro-environmental preferences on bond prices: evidence from green bonds. Journal of Banking and Finance. Vol. 98, pp. $39-60$.

(C) (1)( $)$

(C) 2020 by the authors. Licensee ACRN Publishing, Austria, Editor in Chief Prof. Dr. Othmar M. Lehner. This article is an open access article distributed under the terms and conditions of the Creative Commons Attribution (CC BY SA) license (https://creativecommons.org/licenses/by-sa/4.0/) 